The Research Journal of the Costume Culture

[Original Article]

Received March 14, 2017

Revised April 18, 2017

Accepted April 24, 2017

${ }^{\dagger}$ Corresponding author

(f_art@cau.ac.kr)

ORCID

jihoon Choi

http://orcid.org/0000-0001-8909-0396

mihyun Kim

http://orcid.org/0000-0002-2381-7713

This research was supported by the Chung-Ang University Research Scholarship Grants in 2016.

\section{A study on the VMD elements of fashion select shop interior displays}

\author{
Jihoon Choi and Mihyun Kim ${ }^{* \dagger}$ \\ Dept. of Fashion, Chung-Ang University, Korea \\ Dept. of Clothing \& Textiles, Chung-Ang University, Korea ${ }^{*}$ \\ 패션 셀렉트샵 인테리어 디스플레이의 VMD
구성요소에 관한 연구
}

\author{
최 지 훈·김 미 현 ${ }^{*+}$ \\ 중앙대학교 패션학과, 중앙대학교 의류학과 ${ }^{*}$
}

\begin{abstract}
This study examines the role of visual merchandising (VMD) in creating effective interior displays for fashion "select shops"(shops that carry a wide selection of brands) amid the recent changes in consumption trends, with consumer needs becoming increasingly individualized and diversified. Fashion select shop interior displays can be categorized as self-service, showcase, counter, and environmental display spaces. Regarding the VMD elements that contribute to effective interior displays, we reached the following conclusions. First, in self-service displays, in order to heighten sales efficacy, display elements should be presented in such a way as to enable customers to select products with ease by themselves. Second, the mere presence of showcase displays was found to be insufficient; if, however, select shops use showcase displays to arrange products according to the flow of customer traffic, enabling the creation of a gentrified atmosphere for products, this may contribute to a differentiated image of brands, heightening perceived product value. Third, in counter displays, having a harmonious arrangement of display and presentation elements promotes sales by inspiring customer confidence. Fourth, regarding environmental displays, it is important for stores to have attractive interior designs and decorations in order to reproduce settings in which products are actually used, as this can inspire interest in products and promote customers' purchasing intention.
\end{abstract}

Keywords: fashion select shop(패션 셀렉트삽), interior display(인테리어 디스플레이), $V M D$ elements(VMD 구성요소)

\section{Introduction}

$\mathrm{VMD}$ 는 제품에 정보가치를 부여하고 일정 상품의 이미지를 증대함으로써 매장 에서 상품의 정보와 브랜드의 메시지를 전달하고 이미지를 형성하는 전략이다(Ru, 
2003). 이는 상품을 효과적으로 홍보 및 연출하며, 고 객들에게 강한 구매 욕구를 불러일으킨다. 이에 따라 고객의 구매의도를 높이는 패션 제품의 효과적인 진 열과 구성이 중요한 마케팅 전략으로 강조되고 있다. 최근 확장되고 있는 다양한 품목의 아이템을 판매하 는 셀렉트샵의 경우, 브랜드 아이덴티티를 강조하여 방문 고객을 회유하거나 구매 심리를 촉진시킬 수 있 는 진열과 효과적인 디스플레이와 다양한 $\mathrm{VMD}$ 마케 팅 전략이 필요하다(Sim, 2005). 특히 $\mathrm{VMD}$ 에서 윈도 디스플레이가 시즌을 대표하는 브랜드의 상품을 진 열하여 소비자의 관심과 흥미를 유발한다면, 인테리 어 디스플레이는 매장을 방문한 고객을 매장 안으로 회유하여 실제 구매로 이어지도록 한다.

새로운 유통 형태로 문화와 라이프 스타일을 향유 하는 고객의 취향을 고려하여 다양한 브랜드와 제품 을 한 매장에 모아서 판매하는 셀렉트샵이 주목을 받 고 있는 추세이다. 셀렉트샵의 선행연구로는 Eom (2015), Kim(2004)의 셀렉트샵 마케팅에 관한 연구, $\operatorname{Kim}(2003)$ 의 셀렉트샵 유형별 전략 및 발전 방향에 대한 연구, Kim(2004), Kim and Hwang(2011)의 매 장의 공간 계획이 있다.

본 연구의 목적은 브랜드 커뮤니케이션 전략으로 서 패션 셀렉트샵에서 제공하고 있는 인테리어 디스 플레이를 $\mathrm{VMD}$ 구성요소의 특성과 연출방법으로 살 펴보고, 차별화 된 패션 셀렉트샵의 VMD 전략을 모 색하고자 함에 있다.

구체적인 내용은 다음과 같다. 첫째, 패션 셀렉트 샵의 개념과 인테리어 디스플레이의 $\mathrm{VMD}$ 구성요소 에 관한 이론적 고찰을 통해 방법론을 모색한다. 둘 째, $\mathrm{VMD}$ 구성요소의 관점에서 패션 셀렉트샵의 특 성을 조사한다. 셋째, 셀렉트샵 인테리어 디스플레이 를 $\mathrm{VMD}$ 구성요소의 진열적 요소, 연출적 요소의 관 점에서 특성을 도출한다.

본 연구의 방법은 이론적 고찰과 사례 고찰로 이루 어진다. 전문서적과 선행연구를 바탕으로 셀렉트샵 개념을 이해하고, 인테리어 디스플레이 관점에서 $\mathrm{VMD}$ 구성요소의 특성을 고찰한다. 그리고 셀렉트샵 인테 리어 디스플레이 VMD 구성요소를 진열적 요소와 연 출적 요소로 구분하여 그 특성을 도출한다. 연구의 범위는 최근 패션 셀렉트샵으로 매장수가 증가 추세 에 있는 상위 브랜드인 '에이랜드', '원더 플레이스',
‘어라운드더코너'를 선정하였으며, 이 3개 브랜드가 함께 밀집해 있는 패션 중심지인 가로수길로 그 지역 을 한정하였다. 이들 매장의 공통적 특성은 최근 수 적으로 증가 추세인 패션 셀렉트샵으로 브랜드와 디 자이너가 다른 패션 의류제품과 액세서리뿐만 아니 라, 다양한 라이프 스타일 제품을 함께 유통하고 있 다는 점이다. 이러한 매장 유형은 새로운 체험 마케 팅을 통한 브랜드 커뮤니케이션을 제공하고 있어, 기 존의 인테리어 디스플레이 $\mathrm{VMD}$ 구성요소와 연출 방 법을 살펴보고, 차별화된 마케팅 전략을 모색한다는 데 그 의의가 있다고 할 수 있다.

사례고찰에서 연구 대상인 '에이랜드', '원더 플레 이스', ‘어라운드더코너'의 인테리어 디스플레이 사례 사진 촬영은 방문 고객의 비율이 비교적 적은 평일 오전 시간으로 하였으며, $\mathrm{VMD}$ 의 구성요소인 진열적 요소와 연출적 요소의 관점에서 촬영하였다. 각 브랜 드에서 진열적 요소인 집기, 비주얼 이미지, $\mathrm{POP}$, 소 도구, 조명, 카운터와 연출적 요소의 Visual Presentation(VP), Point of Sales Presentation(PP), Item Presentation(IP)의 대상 사진을 총 320장 촬영하여 연구 관점에 적합한 143 장의 사례 사진을 분석하였다. $\mathrm{VMD}$ 의 구성요소로 조사 및 분류된 사진 자료는 인 테리어 디스플레이의 관점에서 특성을 분석하였다.

변화하는 트렌드와 소비자의 소비 경향을 반영하 여 패션 시장에서도 새로운 유통 형태를 모색하고 있 는 상황에서 다양한 품목을 한 매장에서 판매하는 셀 렉트샵에 대한 소비자의 관심과 욕구가 증가하고 있 어, 다양한 마케팅 전략과 차별화된 매장 $\mathrm{VMD}$ 기획 을 위한 방안 모색에 학술적 의의를 가지고자 한다.

\section{Background}

\section{Understanding fashion select shop}

패션 산업에서 소비자의 취향 다양화와 차별화를 반영하여 머리에서 발끝까지 토탈 패션을 추구하는 경향에 따라 의류와 모자, 가방, 액세서리 등의 잡화 까지 한 매장에서 구매할 수 있도록 다양한 브랜드와 디자이너의 제품을 구성하여 판매하는 매장이 증가 하고 있는 추세이다(Kim, 2003). 이러한 형태의 매장 은 패션 편집매장, 패션 멀티샵, 패션 컨셉샵, 패션 셀 렉트샵이라는 명칭으로 다양하게 사용되고 있는데 
(Eom, 2015), 본 연구에서는 최근 그 용어 정의와 사 용이 선행연구에서 빈번한 패션 셀렉트샵(select shop) 이라고 규정하겠다.

셀렉트샵은 매장에 다양한 브랜드 상품을 사입하 여 판매하는 소매형태로, 브랜드를 구분하지 않고 판 매 컨셉 의도에 따라 공간을 분할하여 이에 맞는 상 품을 구비 및 판매하는 매장이다(Eom, 2015). 이처럼 셀렉트샵은 한 매장에 다수의 브랜드와 다양한 제조 사의 상품을 함께 취급하는 상점으로 매장에 다양한 품목과 한정된 상품으로 매장 컨셉을 설정하고 운영 되는 전문성을 갖춘 소매업의 한 형태이다. 이처럼 패션 셀렉트샵은 감성과 가치를 중시하는 고객을 중 심으로 한 신 개념의 매장을 의미한다(Kim, 2015). 패션 셀렉트샵들은 다양한 디자이너의 제품을 매장 의 특성에 따라 선택 및 편집하여 구성한 것으로 감 성에 호소하며, 가치 중심 소비를 지향하는 고객을 대상으로 한 유통 방식으로, 여러 브랜드 제품 중 고 객의 요구에 맞는 상품을 선정, 관리, 구매, 운영하여 고객이 필요한 상품을 적시, 적가, 적질, 적량에 맞춰 고객에게 서비스와 함께 판매를 제공한다(Eom, 2015). 이러한 셀렉트샵의 개념은 단일 브랜드로 구현할 수 없는 다양한 컨셉 연출 제품을 한 곳에서 구매 가능 하게 하며, 패션샵에서 찾기 힘든 다양한 쇼핑의 체 험 경험을 제공하여 주고, 신진 디자이너나 신진 브 랜드의 시장 진출을 용이하게 한다(Kim, 2003).

셀렉트샵은 한 매장에서 패션관련 제품뿐만 아니 라, 다양한 브랜드의 제품을 판매하면서 트렌드와 문 화를 고객이 직접 체험할 수 있는 문화공간을 제공하 는 역할을 한다(Choi, 2009). 외국의 성공적인 셀렉트 샵은 파리의 '꼴레트'와 이태리의 ' 10 코르소코모'가 있고(Fig. 1), 국내에는 수입브랜드 제품을 유통하는 ‘분더샵'(Fig. 2), 국내 신진디자이너 브랜드 제품을 모아서 판매하는 '난다', '에이랜드', '햇츠온', '폴더', ‘블루핏’이 있는데, 이들 매장에서 고객에게 반응이 좋은 브랜드는 독자적으로 런칭하기도 한다.

\section{Characteristics of VMD elements}

$\mathrm{VMD}$ 는 Visual Merchandising의 약자로 전달기술 로써의 시각화와 상품화 계획을 조합한 단어로써 상 품정책의 시각화 전략이라 할 수 있다(Jang, 2007). 이처럼 $\mathrm{VMD}$ 는 "다른 기업과의 차별화를 이루기 위

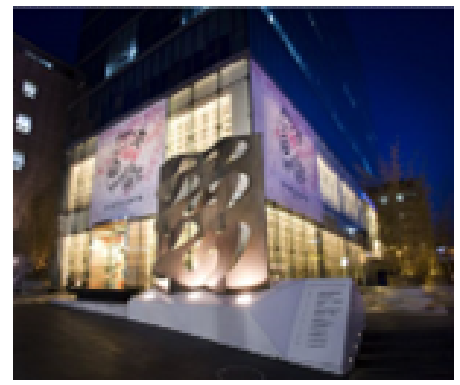

<Fig. 1> 10 Corso Como. From. Chae. (2012). http://www.asiae.co.kr

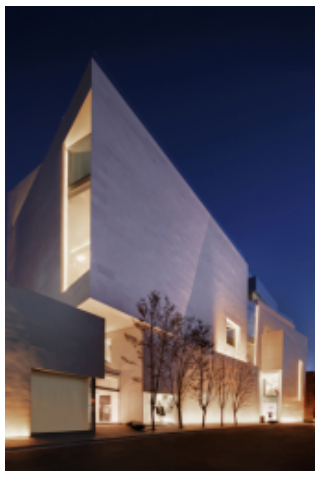

<Fig. 2> Boontheshop. From. Park. (2015). ttp://zine.istyle24.com
하여 상품을 비롯한 모든 시각적 요소를 연출하고 관 리하는 것으로" 상품 전시 디자인 또는 인테리어와 상품 전시 디자인이라고 할 수 있다(Jung, 2008).

$\mathrm{VMD}$ 의 목적은 상품과 브랜드의 이미지를 차별화 되게 표현하여 고객을 회유하는 유통전략이다. 마케 팅에서 프로모션 전략은 매우 중요하다라고 할 수 있 는데, 특히 판매 촉진을 위한 $\mathrm{VMD}$ 는 매장에서 상품 과 브랜드의 이미지를 높이고, 다른 업체와의 차별화 전략으로 고객에게 문화와 서비스 공간을 제공하며, 즐거운 쇼핑분위기를 연출하여 효과적인 매장 구성 을 제시한다(Jung, 2008). 우수한 상품력뿐만 아니라, 그 상품기획을 효과적으로 전달하는 매장은 시각적 이미지를 체계적이고 차별화 되도록 고객들에게 전 달하여 구매 욕구를 만족시킨다.

이러한 $\mathrm{VMD}$ 에서 구성요소는 진열적 요소와 연출 적 요소로 분류된다(Jung, 2011). Jin, Yoon, and Chong(2015), Jung(2011), Kim(2003)은 선행연구에 서 진열적 요소를 집기, 비주얼 이미지, $\mathrm{POP}$, 소도구, 조명, 카운터로 분류하였고, 연출적 요소는 $\mathrm{VP}(\mathrm{Vi}-$ sual Presentation), PP(Point of Sales Presentation), IP(Item Presentation)로 정의하였다. 진열적 요소와 연출적 요소에 관한 내용은 다음과 같다.

\section{1) Display elements}

본 연구에서 진열적 요소는 Jung(2011), Jung (2015), Kim(2003)의 선행연구를 정리하여, 본 연구 에서 집기, 비주얼 이미지, $\mathrm{POP}$, 소도구, 카운터, 조 명으로 분류하였다. 
먼저 집기는 실내에 놓이는 모든 도구류를 지칭하 며, 실내의 기능을 가장 직접적으로 지원하는 요소이 다. 매장구성에서는 연출의 근본이 되며, 상품의 가치 를 높이고, 이미지 전달의 매개체로써 매장의 개성을 만드는 중요한 역할을 한다(Kim, 2005). 대표적 집기 의 종류는 스테이지, 테이블, 행거, 선반, 쇼케이스 등 이 있다. 이는 특히 매장에서 제품을 보관, 정리, 진열 하는 수납의 기능을 가지며(Jang, 2010), 실내 장식적 요소로도 작용하여 미적 효과를 증대시키는 역할을 한다. 소도구는 상품을 돋보이게 하는 것으로 디스플 레이가 목적이 되는 적극적인 판매 기술이다. 소도구 의 종류에는 상품의 효과적인 연출을 도와주는 두상, 손, 발 모양의 소도구가 많이 활용된다. 이는 상품의 특성을 표현하고, 가치를 돋보이게 하여 상품 연출의 효과를 높이고, 시선을 집중시키는 역할을 한다.

진열적 요소에서 비주얼 이미지(visual image)는 매장의 마케팅 일환으로 브랜드를 차별화 시키는 요 소이다. 일반적으로 비주얼 이미지는 브랜드 광고의 사진 컷을 포스터로 매장을 장식하거나(Shin, 2003), 패션 트렌드에 맞는 이미지나 그래픽 이미지를 액자 형이나 배너형으로 사용한다. 특히 스타마케팅을 활 용한 포스터는 한류의 영향으로 외국인 관광객이 많 아지고 있는 현실을 고려할 때, 그 광고 효과가 매우 높다. 최근에는 디지털 파사드 등을 활용하여 매장의 제품을 홍보하기도 하고, 매장의 인테리어 콘셉트에 따라 다양하게 사용하고 있는 추세이다. Point of Purchase(POP)는 고객의 쇼핑을 위한 상품의 정보를 게시하는 표시물을 의미한다. 매장 내에서 현수막, 포 스터, 배너, 시안, 쇼카드, 정보안내지, 상품 설명 $\mathrm{POP}$ 등이 이에 해당된다. $\mathrm{POP}$ 는 상품의 정보제공과 고객에게 상품을 판매의 최종 단계로 연결시키는 매 개체 역할을 한다((Bahk, 2007). 고객의 눈에 띄는 곳 에 진열하여 신제품 출시를 알리거나, 사은품 관련 정 보와 세일을 고객에게 보다 효과적으로 전달한다. 카 운터는 매장에서 고객이 구매하고자 하는 제품의 값 을 계산하는 곳이다. 이는 종업원들의 서비스와 상품 이 고객의 구매동선을 볼 수 있게 하여 제품의 구매 를 확신시켜 주는 곳이다(Jang, 2010). 마지막으로 진 열적 요소에서 조명은 분위기 연출의 기본적인 요소 로써 매장 공간 내에서의 상품을 밝히고, 판매 공간 내에서 상품의 아이덴티티를 강조하고, 동선을 유도
하며, 조도의 차이를 주어 공간 연출을 극대화 하는 역할을 하고 있으며, 조명에는 기본조명, 상품조명, 환경조명이 있으며, 고객을 회유하는 시각적 효과를 나타내어 쾌적한 매장 분위기를 연출한다(Oh, 2004).

\section{2) Presentation elements}

연출적 요소는 Jung(2011), Jung(2015), Kim(2003) 의 선행연구를 정리하여 Visual Presentation(VP), Point of Sales Presentation(PP), Item Presentation(IP) 로 구분하였다. 연출적 요소의 Visual Presentation $(\mathrm{VP})$ 는 연출 테마의 종합 표현으로 매장과 상품의 이 미지를 전달하는 역할을 하고, 매장에서 가장 시선을 끄는 장소인 쇼윈도나 주입구에 VP가 주로 제시된 다. VP를 구성하는 요소로는 매장 입구의 쇼윈도와 매장내의 스테이지, 테이블 연출 공간으로써 시즌별 또는 특별행사의 상품기획 콘셉트를 표현하는 것이 다. VP는 매장의 얼굴이라고 할 수 있으며, VMD 전 개의 가장 중점적인 부분으로 고객에게 계절 테마 또 는 패션 테마에 맞추어 매장의 이미지를 시각적으로 제시하고, 제품을 보여주는 역할을 한다.

Point of Sales Presentation(PP)는 분류된 제품의 판매 포인트를 보여 주는 것으로, 페이스 상단 상품 과 행거 앞 마네킹 공간을 나타낸다. 판매하고자 하 는 상품, 디자인, 스타일 등을 벽면스테이지, 선반의 상단, 행어집기의 앞면 등에 판매 포인트를 제공하고, 조명과 소품류 등을 활용하여 그 연출 효과를 높인 다. VP와 IP를 자연스럽게 연결하며, 고객의 동선 흐 름을 염두에 두면서 진열할 위치를 정해 고객의 구매 욕구를 자극시키고, 고객의 구매동선을 매장의 구석 구석으로 회유 및 확대시키는 역할을 한다.

Item Presentation(IP)는 여러 제품을 분류, 정리하 여 보기 쉽고 고르기 쉽게 진열하는 것을 의미한다. 매장 내에서 행거와 선반 등의 쇼케이스 연출 공간으 로써 실제 판매가 이루어지는 곳으로 고객이 상품을 선택하기 쉽게 품목별로 분류 및 정리하여 고객이 직 접상품을 선택할 수 있게 하여 구매로 연결시키는 역 할을 한다.

\section{Types of interior displays}

$\mathrm{VMD}$ 에서 윈도 디스플레이가 시즌을 대표하는 브 랜드의 상품을 진열하여 소비자의 흥미를 유발한다 


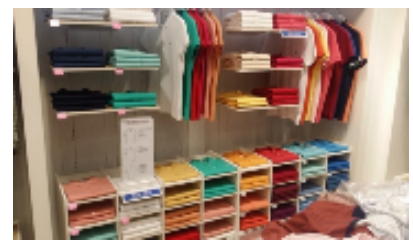

<Fig. 3> Self service Tommy Hilfiger. From. Junjun. (2015). http://cafe.naver.com

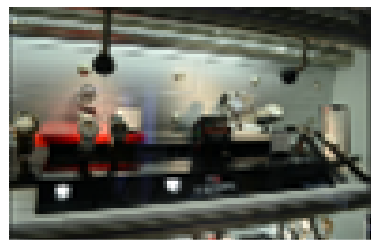

$<$ Fig. 4> Show case display Tissot. From. Camouflage. (2014). http://blog.naver.com

면, 인테리어 디스플레이는 매장을 방문한 고객을 매 장 안으로 회유하여 실제 구매로 이어지도록 하는 목 적을 가지고 있다(Lee, 1998).

이러한 인테리어 디스플레이는 최근 윈도 쇼케이 스가 없는 매장이 많아지면서 그 중요성이 강조되고 있다. 이러한 인테리어 디스플레이는 동선의 길이를 길게 만들어 고객이 매장에 머무는 시간을 늘려 구매 를 높이는 역할을 한다. 대표적인 사례로는 의류 매 장에서 할인코너에 가려면 정상가 판매대를 거쳐서 가도록 유도하는 것이다.

이처럼 인테리어 디스플레이는 매장을 방문하는 고객에게 매장 입구에서부터 매장 내에 이르는 고객 의 동선이 효과적으로 구성되도록 디스플레이를 하 는 것이다. 매장에서 제품을 직접 보고 체험할 수 있 도록 하는데, 상품 진열의 방법에 따라 분류하면 셀 프서비스, 쇼케이스, 카운터, 환경 디스플레이로 공간 이 구분된다(Jung, 2001).

인테리어 디스플레이에서 셀프서비스 디스플레이 공간은 고객이 마음에 드는 제품을 직접 선택할 수 있도록 하는데, 원하는 제품을 손쉽게 만져보고 관리 하기가 용이하게 한다. 〈Fig. 3〉에서처럼 테이블이나 진열장을 활용하여 제품을 편리하게 고객이 고를 수 있도록 진열하고 있다. 다품종 소량 제품 판매를 원 칙으로 하는 대형 SPA 매장에서 주력하는 디스플레 이 방식으로 점원을 대신하여 고객이 쉽게 원하는 제 품을 선택할 수 있도록 도와준다.

쇼케이스 디스플레이는 유리케이스 안에 상품을 전시하는 것으로 주로 매장의 벽면이나 판매대 뒤에 위치한다. 〈Fig. 4〉에서처럼 쇼케이스 디스플레이는 판매원의 도움으로 상품에 접근할 수 있기 때문에 고 가의 액세서리 등이 진열되는 공간 연출이 된다.

카운터 디스플레이는 계산대 옆에 상품을 진열하

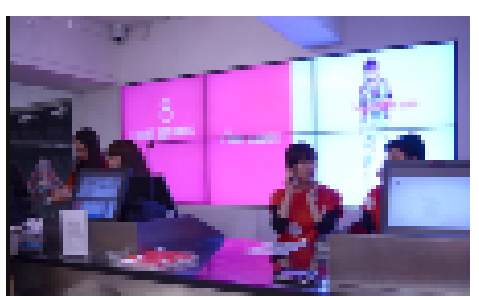

<Fig. 5> 8 seconds counter display. From. Camouflage. (2012). http://blog.naver.com

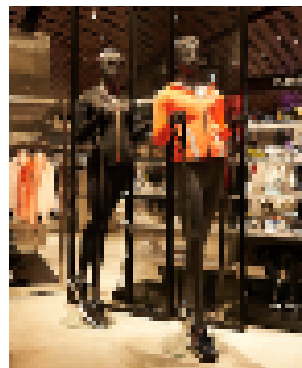

<Fig. 6> Descente Enviroment display. From. Descente. (2016). http://blog.naver.com
는 것으로 고객의 충동구매를 자극할 수 있어 $\mathrm{POP}$ 등과 함께 판매를 보조하는데 활용된다(Fig. 5). 보통 구매한 의류 제품과 코디가 가능한 양말, 벨트 및 가 방이나 액세서리를 진열하여 구매를 유도한다. 최근 에는 디지털 파사드를 활용하여 상품정보와 연출 방 법을 시각적 이미지를 통해 홍보하여 추가 구매를 하 도록 하는 역할을 수행한다.

환경 디스플레이는 제품이 사용되는 상황을 그대 로 재현하는 것으로, 일반적으로 다양한 판매 제품과 소품을 세팅하여 활용 방법 등을 상황으로 연출하여 구매를 유도한다. 〈Fig. 6〉에서처럼 환경 디스플레이 는 제품이 사용되는 상황을 실제처럼 그대로 재현한 것을 말한다. 제품과 소품들은 실제 사용 상황의 세 팅으로 진열하여 고객들이 구매 전에 패션 제품의 사 용 상황을 간접적으로 체험하여 구매를 유도하게 만 든다.

$\mathrm{VMD}$ 에서 디스플레이가 전략적으로 매우 중요한 역할을 하는데, 그중에서도 특히 다양한 브랜드의 아 이템을 유통시키는 패션 셀렉트샵의 경우, 고객의 구 매를 유도하는 매장안의 인테리어 연출의 기획은 차 별적으로 진행되어야 할 것이다.

\section{Case Analysis of Fashion Select Shop VMD Display Elements}

\section{VMD display elements of ALAND}

에이랜드(ALAND)는 신진 디자이너 패션 셀렉트 샵으로 컨템포러리 감성의 캐주얼과 의류, 신발, 문구 등 디자이너 손길이 닿을 수 있는 모든 개성 있는 디 자인 상품을 한 매장에서 제안하고 있다. 에이랜드는 
디자이너 브랜드 창업을 희망하는 신진 디자이너들 에게 진입 장벽을 낮춰 주었고, 이후 단독 브랜드로 성장할 수 있도록 배경을 만들어 주었다. 디자이너 편집샵 에이랜드는 명동, 가로수길, 홍대, 강남역 등 국내에만 10 개 매장을 오픈하는 등 확장 추세에 있으 며, 홍콩으로 진출하여 4 개 매장을 운영하는 등 해외 로도 진출을 시도하고 있다. 최근에는 유동인구가 밀 집하는 국내 대형 유통몰로의 진출이 늘어가고 있는 추세이며, 그 매장의 수가 늘어나고 있다(Aland, 2016).

에이랜드의 $\mathrm{VMD}$ 구성 요소를 진열적 관점의 집 기, 소도구, 비주얼 이미지, Point of Purchase(POP), 카운터, 조명으로 분류하여 살펴보겠다. 먼저 진열적 요소에 속하는 집기에서 〈Fig. 7〉과 같은 테이블은 제 품 보관 및 정리 공간으로 활용되면서, 고객이 손쉽 게 제품을 고를 수 있는 셀프서비스 디스플레이를 하 고 있었다. 높낮이가 다른 테이블은 제품의 영역과 공간을 분리하면서 미적 효과도 높여 장식적 역할도 겸하고 있었다. 집기로 활용된 두상 없는 마네킹은 고객의 시선을 유도하고, 매장내 상품 정보를 제공하 여 동선을 최적화시켜 쇼핑의 편리성을 높이는 것으 로 나타났다. 브랜드를 구분하는 라인별 마네킹은 주 력 상품을 효과적으로 전시하여 상품 연출 효과를 높 이고 있었다. 진열적 요소에서 소도구는 모자와 같은 패션 소품을 강조하는 마네킹 두상 모형이 활용되고 있었는데, 상품을 간접체험하게 하고, 돋보이게 하는 역할을 하고 있었다. 비주얼 이미지는 매장의 마케팅 일환으로 브랜드를 차별화 시키는 역할을 하고 있었 는데, 에이랜드는 브랜드 심볼인 물고기 이미지를 부 착하여 브랜드를 알리는 홍보 역할을 하고 있었다. $\mathrm{POP}$ 는 고객의 편리한 쇼핑을 도와주는 역할을 하고 있었는데, 상품의 정보를 나타내는 역할로 상품에 대 한 이해를 돕고, 라인별로 상품 종류를 구분해 준다. 카운터는 매장 중앙 벽면에 위치하며 포스터와 함께 브랜드 홍보 효과를 내고 있으며, 고객들의 쇼핑 동 선을 넓게 하고, 카운터 뒤에도 제품을 진열하여 계 산을 할 때도 제품에 시선이 머무르게 한다. 조명은 상품의 식별, 매장안내, 주목률, 제품 가치를 높이는 역할을 하고 있었으며, 편안한 쇼핑 분위기 속에서 상품에 포인트를 연출하였다.

에이랜드의 연출적 요소를 $\mathrm{VP}, \mathrm{PP}, \mathrm{IP}$ 의 관점에서 살펴보면, $\mathrm{VP}$ 는 고객을 매장 안으로 유도하고 회유

하며, 시즌 트렌드를 반영하는 역할을 하는 쇼윈도, 매장 입구의 매인 스테이지, 테이블 중앙 연출 공간 으로 구분하고 있었다. 쇼윈도는 고객들이 매장 안으 로 쉽게 들어올 수 있도록 개방되어 있었으며, 매장 입구와 스테이지에는 많은 집기류들을 배치하여 고 객의 시선을 끌고 있었다(Fig. 11).

$\mathrm{PP}$ 는 디자인 포인트를 제안하여 판매를 유도하는 역할을 하고 있었으며, 페이스 상단 상품, 행거 앞 마 네킹 공간으로 되어 있었다(Fig. 12). 벽면 상단에 가 방 소품을 배치하고, 집기류 상단 공간에는 연관되는 소품들과 의류들을 배치하고 있었다.

$\mathrm{IP}$ 는 PP와 연결하여 자연스럽게 상품이 배치되게 하는 역할을 하고 있었으며, 행거와 선반 등의 쇼케 이스 연출 공간으로 연출되었다. 행거를 벽면에 일렬 로 배치하여 브랜드별 제품 라인이나 영역을 인식하 기 쉽게 수평 진열하여 고객들이 보기도 쉽고, 고르 기도 쉽게 진열하고 있었다(Fig. 13). 그리고 쇼케이 스에서는 고가의 액세서리와 시계, 안경 등을 진열하 여 다른 제품과 코디를 원활하게 할 수 있는 정보를 제공하고 있었다.

\section{VMD display elements of WONDERPLACE}

원더플레이스(WONDERPLACE)는 'NO.1 LIFE STYLE CONCEPT STORE'를 지향하는 패션 리테일 기업이다. 원더플레이스는 다양한 스타일링과 새로운 라이프 스타일 아이템을 선보이는 편집매장으로 합 리적인 가격대의 국내외 패션 브랜드, 신진 디자이너

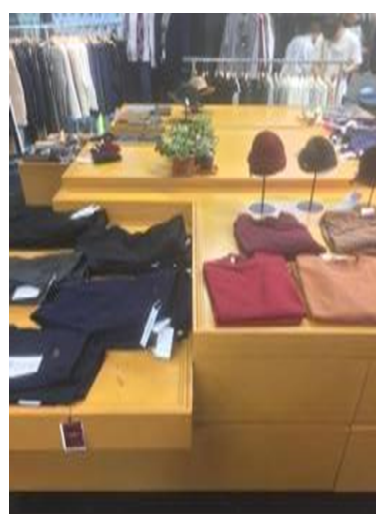

<Fig. 7> ALAND fixtures. Photographed by the author. (October 23, 2016)

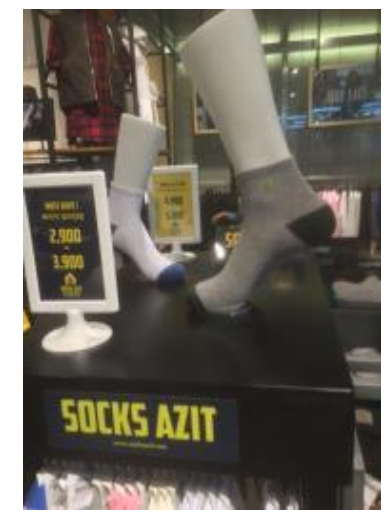

<Fig. 8> Wonder Place Props. Photographed by the author. (October 27, 2016) 
컬렉션, 콜라보레이션 상품, 레이블을 고객 타겟에 맞 게 구성해 새로운 문화공간을 추구하고 있다(Wonderplace, 2016).

원더플레이스에서 먼저 진열적 요소를 살펴보면 집기는 테이블을 활용한 편리하고 효율적인 셀프서 비스 디스플레이에 활용되어 고객의 쇼핑을 돕고 있 었으며, 연계 상품과 액세서리를 함께 배치하여 상품 의 스타일링 가치를 높이고, 쇼핑 포인트를 유도한다. 마네킹은 바디 마네킹으로 높낮이가 조절되기 때문 에, 진열 연출에 유리할 뿐 아니라 공간을 작게 차지 하여 스테이지를 보다 다양하게 활용할 수 있도록 하 였다. 또한 벽면에 부분 연출용 컬러나 재질의 통일 감이 매장을 정돈되어 보이게 하는 효과를 주고 있었 다. 소도구는 발모양 마네킹을 활용하여 소도구로써 상품의 특성을 표현하고, 다른 상품들과의 조화를 높 이는 역할을 하고 있었으며(Fig. 8), 테이블 위에 소도 구를 진열하여 고객들의 시선을 집중시켜 저가의 양 말 소품에 가치를 부여하고 있었다. 비주얼 이미지는 최근 활용도가 높아지고 있는 디지털 파사드로 브랜 드 특성을 홍보하는 역할을 하고 있었으며, 고객의 이목을 집중시키고 브랜드 이미지를 심어 주고 있었 다. $\mathrm{POP}$ 는 신상품을 알리는 상품 안내 $\mathrm{POP}$ 로 상품의 특징과 정보를 전달하는 역할을 하고 있었다. 이는 상품의 특징, 소재, 가격 등을 알려주어 신뢰감을 높 이고, 상품에 대한 이해를 돕고 있었다. 카운터에 디 지털 스크린을 설치하여 고객들의 관심을 유도하는 역할을 하고 있었으며(Fig. 9), 동선이 짧아 POP와 상

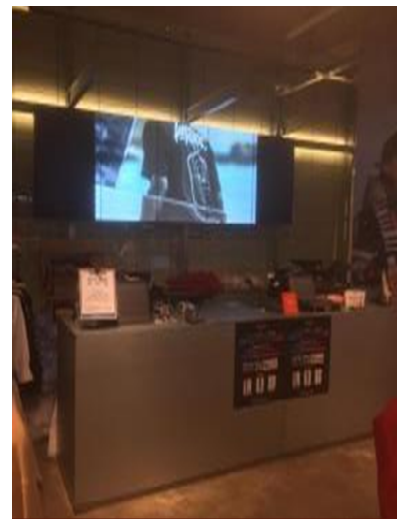

<Fig. 9> Wonder Place digital facade. Photographed by the author. (October 27, 2016)

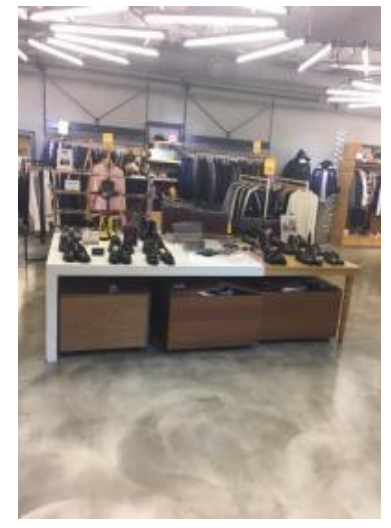

$<$ Fig. 10> Around the Corner. Photographed by the author. (November 3, 2016)
품 진열을 같이하여 고객의 시선을 집중시키고 있었 다. 조명은 매장을 눈에 띄게 하고, 고객을 유도하는 역할을 하고 있었으며, 상품을 잘 보이게 하기 위하 여 매장 앞까지 조명이 있었으며, 주목률과 가치를 높이고 외부에서도 한눈에 보인다.

원더플레이스의 연출적 요소에서는 $\mathrm{VP}$ 를 나타내 는데, 고객을 유도하고 회유하는 역할을 하고 있었으 며(Fig. 14), 매장 입구, 쇼윈도, 매장내의 스테이지, 테이블을 활용하여 연출하고 있었다. 원더플레이스 매장의 입구는 대체적으로 개방 형태로 이루어져 있 어, 입구의 $\mathrm{VP}$ 를 활용한 연출은 매장 안으로 바로 연 결되어 있어 고객들의 접근이 용이하며, 테이블에는 의류, 모자, 신발 등을 함께 진열하여 관련 제품의 연 관 배치에 주력하고 있었다.

원더플레이스의 연출적 요소에서 $\mathrm{PP}$ 는 그 시즌 트 렌디한 상품을 돋보이게 하는 역할을 하는데, 〈Fig. $15>$ 에서처럼 페이스 상단 상품, 행거 앞 마네킹 공간, 페이스 상단을 말하며, 그 시즌에 가장 트렌디한 상 품을 진열하고 있었다. 마네킹은 조명과 함께 배치하 여 시각적으로 주목성을 가지며, 매장안의 세련미와 공간구성 연출을 하는데 쓰이고 있었다.

IP는 시각적인 효과를 극대화 하는 역할을 하며, 〈Fig. 16〉과 같은 행거와 선반 등의 쇼케이스 연출 공 간을 나타내는데 아이템의 스타일, 브랜드별, 사이즈, 칼라 별로 그룹 수직 진열과 수평 진열을 하여 고객 들이 고르기 쉽도록 진열하고 있었다.

\section{VMD display elements of around the corner}

어라운드더코너는 우리들의 삶의 새로운 감성과 경험이 되기를 희망하는 의미를 가지고 있으며, 패션 은 물론 뷰티를 비롯한 문구류에서 음식까지 라이프 스타일 전반을 아우르는 셀렉트샵 브랜드이다. 어라 운드더코너는 2012년 가로수길에 처음 문을 연 '라이 프 스타일 \& 패션 편집 스토어'로 국내·외 신진 디자 이너 및 크리에이터들을 양성하고, 현재의 감성과 스 타일을 공유하며, 새로운 문화와 가치를 경험할 수 있으며, 합리적인 가격으로 가치소비를 추구하는 젊 은 소비자에게 어라운드더코너만의 독특한 스타일을 제안한다. 어라운드더코너는 패션 셀렉트샵이 아니 라, 개성 있는 브랜드들이 자연스럽게 어울려 창의적 디자인 제품의 가능성과 비전 그리고 영감을 발견하 는, 모든 창조와 라이프 스타일을 공유할 수 있는 공 
간을 추구한다(Around the corner, 2016).

어라운드더코너에서 진열적 요소에서 집기는 매장 의 표정과 개성을 만드는 역할을 하고 있었으며, 단 품 위주의 상품이 진열되지만, 행거를 같이 두어 관 련 상품 연계 진열이 용이한 디스플레이를 하고 있었 다. 소도구의 활용에서 마네킹은 풀코디 중앙의 마네 킹 존에 임팩트를 주어 주력 상품에 시선을 집중을 시키고 있었다. 진열적 연출에서 소도구를 나타내는 마네킹은 매장의 주력 상품들을 시각적으로 코디하 여 제품 정보를 소개하고 활용 방법을 제안하여 고객 의 시선을 집중시킨다. 비주얼 이미지는 광고 사진을 활용하고 있었는데, 브랜드 홍보와 매장 분위기 연출 을 위한 장식적 기능을 하며, 인테리어 조명으로 시 선을 집중시켜 해당 상품들에게 한 번 더 눈길이 가 게 만든다. $\mathrm{POP}$ 는 시즌 분위기와 행사 안내를 연출하 는데, '앤더슨벨 $\times$ 어라운드더코너'의 콜라보레이션 작 업 홍보는 신진디자이너의 영역 확장과 진출을 돕기 도 한다. 포스터로 행사관련 상품을 안내하며 상품 설명과 세일 안내를 돕기도 한다. 어라운드더코너의 카운터는 다른 브랜드와는 차별되게 매장의 중앙에 위치해 있어, 구매를 확정한 고객의 동선을 짧게 유 도하고 공간을 분리하는 역할을 하고 있었다. 어라운 드더코너 매장의 조명은 대체적으로 형광등을 사용 하여 매장을 밝게하여 밝은 분위기에서 상품의 연출 과 진열로 고객들이 편안하게 쇼핑할 수 있는 분위기 연출을 하고 있었다(Fig. 10).

어라운드더코너의 연출적 요소에서 $\mathrm{VP}$ 는 다른 브 랜드와는 차별적으로 쇼윈도에 마네킹을 활용하고 있었으며, 〈Fig. 17〉과 같은 연출로 매장과 상품의 이 미지를 높이는 역할을 하고 있었다. 매장 입구의 쇼 윈도, 매장내의 스테이지, 테이블은 VP의 대표적 연 출 공간으로, 입구에 조명과 독특한 매장 인테리어로 고객들의 시선을 유도하여 매장 안으로 고객들을 회 유하는 역할을 한다. 매장 내의 테이블 연출에서는 이벤트 상품을 진열하여 고객의 흥미를 유발하게 하 고 있었다.

어라운드더코너의 PP는 〈Fig. 18〉에서처럼 트렌디 한 제품을 연출하여 고객의 시선을 자연스럽게 이끄 는 역할을 하고 있었으며, 페이스 상단 상품, 행거 앞 마네킹 공간이다. 페이스 상단에는 그 시즌에 가장 트렌디한 상품을 진열하고, 마네킹은 상반신 마네킹
으로 풀 코디 착장하여 진열하고 있었다.

$\mathrm{IP}$ 는 집기를 비롯하여 전체 매장이 조화롭게 보이 는 역할을 하고 있었으며(Fig. 19), 행거와 선반 등의 쇼케이스 연출 공간이다. 관련 상품을 연계 진열하여, 상품 스타일에 따른 행거 진열을 하며, 행거위에 모 자와 같은 제품들을 진열하여 매장 내에서 조화롭게 연출되고 있었다.

\section{N. Characteristics of VMD Elements of Fashion Select Shop Interior Displays}

\section{Characteristics of VMD elements of fashion} select shop

국내에서 활발하게 확장 추세에 있는 패션 셀렉트 샵의 $\mathrm{VMD}$ 연출을 진열적 요소와 연출적 요소로 구 분하여 살펴본 내용은 다음과 같다.

패션 셀렉트샵의 $\mathrm{VMD}$ 연출에서 진열적 요소는 셀렉트 샵의 특성상 다양한 브랜드와 디자이너 그리 고 의류제품 외에 관련 소품을 한정된 공간에 효과적 으로 진열 및 연출하여 판매하는 매장의 특성을 반영 하여 공간을 분리하는 역할을 한다. 이러한 진열적 요소는 집기, 소도구, 비주얼 이미지, $\mathrm{POP}$, 카운터, 조명 등으로 구분되어 연출된다.

먼저 진열적 요소에서 집기는 스테이지, 테이블, 행거, 선반 쇼케이스로 구분되는데, 스테이지는 매장 의 신제품이나 주력 상품을 부각시켜 판매 상품을 시 각적으로 강조하는 역할을 한다. 그러나 패션 셀렉트 샵의 특성상 의류 상품뿐만 아니라, 다양한 액세서리 와 그 외 라이프 스타일을 포괄하는 관련 소품을 함 께 판매하고 있기 때문에, 많은 공간을 차지하는 연 출적 요소는 자제되고 있었다. 에이랜드의 경우, 판매 제품을 진열시 공간적으로 한계가 있어 많은 공간을 필요로 하는 스테이지를 활용한 진열적 연출은 자제 되고 있었다. 그러나 집기에서 테이블의 경우는 메인 상품과 소품 액세서리, 가방, 신발, 장갑, 스카프 등을 효과적으로 진열할 수 있기 때문에, 높이가 높은 테 이블을 활용하여 제품을 고객이 직접 손으로 만져서 체험할 수 있도록 고객의 쇼핑 편의를 고려한 진열로 다양한 시즌 제품을 진열하고 있었다(Fig. 7). 원더플 레이스는 테이블 위에 주력 상품과 연계 상품의 진열 을 함께 배치하여 $\mathrm{VP}$ 존에 대표적인 상품을 보여주는 
용도로 활용하고 있었으며, 이는 고객들에게 시각적 주목성을 높여 상품 정보를 제공하며, 판매를 유도하 는 역할을 하고 있었다. 집기에서 행거는 많은 공간 을 차지하지 않고 물품을 효과적으로 정리 및 구분하 는데 유용하므로, 많은 다양한 브랜드의 아이템을 진 열해야 하는 셀렉트샵에서 주력적으로 활용하는 것 으로 나타났다. 그 예로 어라운드더코너에서는 브랜 드별 단품 상품을 아이템으로 구분하여 테이블 위에 연출하면서, 함께 코디가 가능한 연관 제품 행거를 옆에 두어 관련 상품과의 연계 진열이 용이한 형태로 배치되어 주력 제품외의 상품의 정보 전달을 용이하 게 하고 있었다.

진열적 요소에서 소도구는 주로 마네킹이 사용되 는데, 전신, 두상, 손, 발 등이 제품 아이템 구분에 따 라 활용되며, 많은 제품 아이템의 연출 공간에 제한 이 있어 전신 마네킹보다는 공간을 적게 차지하면서, 제품 진열을 강조할 수 있는 인체 부분 마네킹이 주 로 사용되고 있었다. 에이랜드는 많은 소도구를 사용 하지 않으며, 세련된 매장 연출로 모던한 이미지를 강조하고 있었고, 이와 비교적으로 원더플레이스와 어라운드더코너는 소도구를 활용하여 주력 제품을 시각적으로 홍보 및 연출하고 있었다(Fig. 8). 인체부 분 마네킹 활용은 저가의 소품에 가치를 부여하여 고 객의 시선을 집중시키며, 공간을 많이 차지하지 않으 면서 다양한 진열이 가능하여 제품의 착장 이미지를 간접 체험하도록 강조한다. 연구대상 패션 셀렉트샵 매장들은 모두 전신 마네킹보다는 인체 부분 모형의 마네킹 소도구를 활발하게 사용하여 상품 진열 연출 을 하는데 중점을 두고 있었다.

다른 브랜드와의 차별화를 연출할 수 있는 비주얼 이미지는 스타 마케팅 광고 사진, 일러스트, 디지털 파사드 등으로 표현되는데, 에이랜드는 매장 안에 비 주얼 이미지를 사용하지 않고 있었지만, 외부에 브랜 드를 알리는 심볼 비주얼 이미지를 통해 브랜드를 각 인시키고 있었다. 일반적으로 비주얼 이미지는 조명 을 통해 강조되어 고객에게 브랜드의 차별된 아이덴 티티를 인식시킨다. 어라운드더코너 매장에서는 광고 이미지 컷 사진으로 시선을 집중시켜 고객을 회유하 고, 관련 상품에 눈길이 가도록 만들고 있었다. 에이 랜드와 어라운드더코너는 비주얼 이미지를 소극적으 로 활용하고 있었고, 원더플레이스에서는 최근 그 활
용도가 다양해지고 있는 디지털 파사드를 사용하여, 브랜드와 시즌 제품 정보를 홍보하는데 큰 역할을 하 고 있었다(Fig. 9). 이처럼 한 매장에 다양한 브랜드가 유통되는 셀렉트샵에서 개별 브랜드나 디자인너를 고객에서 각인시키기 위해서 비주얼이미지는 효과적 인 것으로 나타났다.

상품정보 제공에 유용한 $\mathrm{POP}$ 는 포스터, 현수막, 배너, 쇼카드, 시안, 정보안내지, 상품 설명 $\mathrm{POP}$ 등으 로 나타난다. 에이랜드와 원더플레이스는 상품 설명 $\mathrm{POP}$ 를 제품 아이템 별로 배치하여 상품에 대한 이해 를 돕고 쇼카드로 상품 종류를 구분해 주었다. 최근 패션 브랜드와 디자이너의 콜라보레이션이 주목받고 있는 시점에서, 어라운드더코너의 '앤더슨벨 $\times$ 어라운 드더코너' 콜라보레이션 제품 행사관련 상품을 안내 와 같은 $\mathrm{POP}$ 는 상품 설명과 프로모션을 동시에 홍보 하는 효과를 유도하는 것으로 나타났다. 에이랜드와 원더플레이스에서는 $\mathrm{POP}$ 를 상품에 대한 이해와 상품 종류를 구분해 주는데 활용하는 반면, 어라운드더코 너는 행사관련 상품을 안내하며, 광고매체의 역할까 지 하는 연출 효과를 나타내고, 있어 앞으로 활용 가 능성을 높일 필요성이 강조되었다.

고객의 구매를 결정짓는 카운터의 벽면 상품 진열 이나 디지털 화면은 고객들의 쇼핑동선을 넓게 하며, $\mathrm{POP}$ 와 상품 진열은 고객의 시선을 상품으로 회유하 는 효과가 있다. 특히 매장의 안쪽 중앙에 카운터가 위치하면 고객이 매장 안까지 오도록 동선을 조정하 면서, 공간을 좌우로 분리하는 역할을 하는 것으로 나타났다. 특히 최근 브랜드 홍보와 제품을 알리는 비주얼 이미지나 디지털 파사드가 카운터 후면과 측 면에 위치하여 광고 효과를 나타내고 있으며(Fig. 9), 에이랜드와 어라운드더코너는 액세서리와 같은 소품 을 카운터 후면에 진열하여 판매를 촉진시키는 연출 을 한다.

인테리어 디스플레이에서 조명은 매장의 쾌적한 분위기를 조성하고 강조하는 역할을 하는데, 종류는 기본조명, 상품조명, 환경조명이 있다. 에이랜드는 천 장조명으로 편안한 분위기 속에서 상품에 포인트 조 명 연출을 하여 주목률과 가치를 높이고, 외부에서부 터 한 눈에 띄게 하는 연출을 하였다. 에이랜드와 어 라운드더코너는 형광등을 사용하여 환하고, 생동감 있게 연출을 하고 있었으며, 원더플레이스에서는 주 
$<$ Table 1> Case analysis of fashion select shop VMD presentation elements

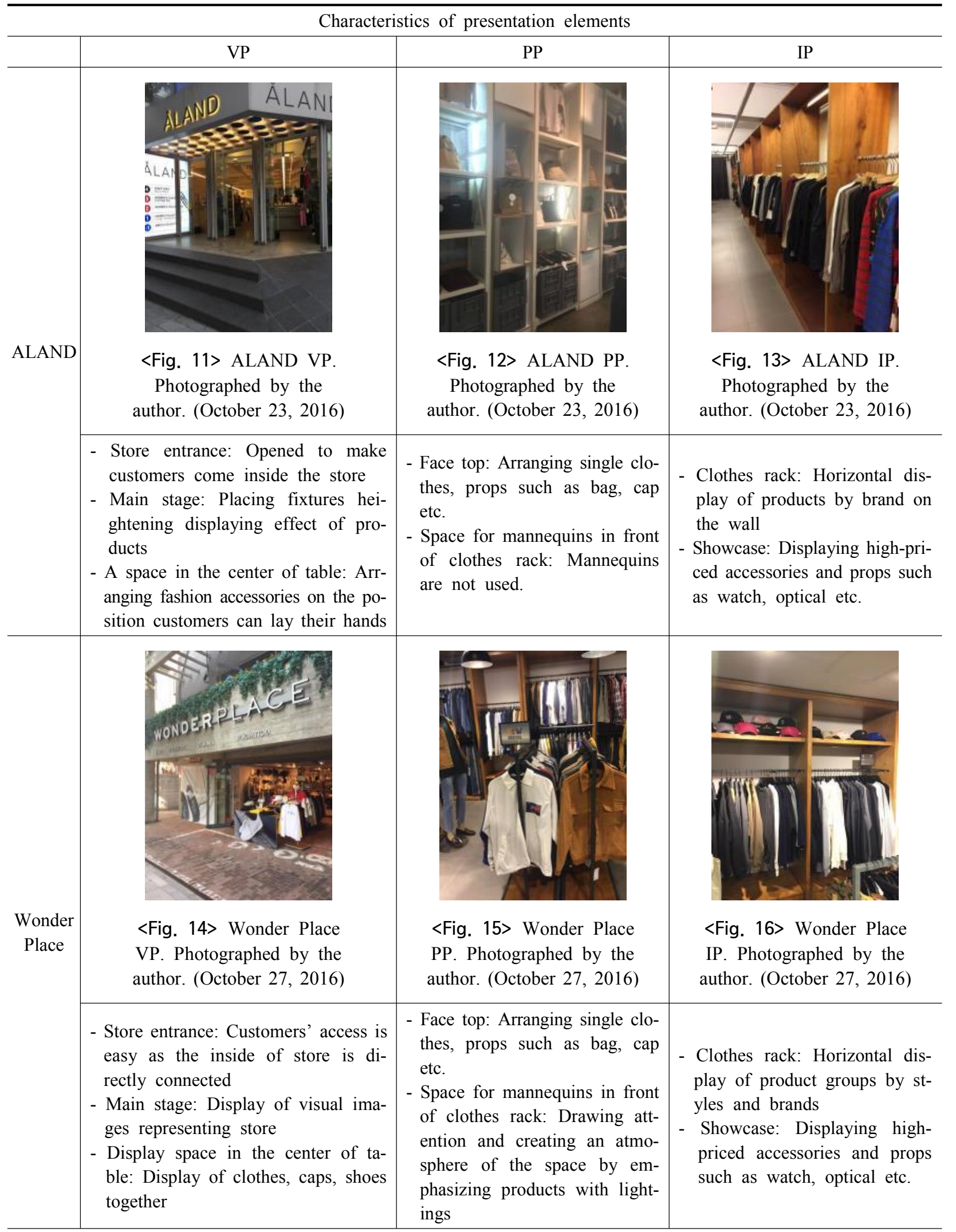




\begin{tabular}{|c|c|c|c|}
\hline \multicolumn{4}{|c|}{ Characteristics of presentation elements } \\
\hline \multirow{3}{*}{$\begin{array}{l}\text { Around } \\
\text { the } \\
\text { Corner }\end{array}$} & VP & PP & IP \\
\hline & $\begin{array}{l}\text { <Fig. 17> Around the } \\
\text { Corner VP. Photographed } \\
\text { by the author. (November } \\
\text { 03, 2016) }\end{array}$ & $\begin{array}{l}\text { <Fig. 18> Around the } \\
\text { Corner PP. Photographed } \\
\text { by the author. (November } \\
\text { 03, 2016) }\end{array}$ & $\begin{array}{l}\text { <Fig. 19> Around the } \\
\text { Corner IP. Photographed } \\
\text { by the author. (November } \\
\text { 03, 2016) }\end{array}$ \\
\hline & $\begin{array}{l}\text { - Store entrance: Drawing atten- } \\
\text { tion with lighting and unique } \\
\text { store interior } \\
\text { - Main stage: Created to induce } \\
\text { customers } \\
\text { - Table center: A space for display- } \\
\text { ing event products }\end{array}$ & $\begin{array}{l}\text { - Face top: Displaying the most } \\
\text { trendy products of the season } \\
\text { - Space for mannequins in front } \\
\text { of clothes rack: Displaying full- } \\
\text { decorated upper body manne- } \\
\text { quin }\end{array}$ & $\begin{array}{l}\text { - Clothes rack: Displaying acc- } \\
\text { ording to product styles by dis- } \\
\text { playing relevant products } \\
\text { - Showcase: A space for display- } \\
\text { ing socks, accessories etc. }\end{array}$ \\
\hline
\end{tabular}

황색 등을 사용하여 눈부심이 적고 화사하며 편안한 느낌을 준다(Fig. 10). 이처럼 조명은 연출에 따라 쇼 핑환경과 매장 분위기 연출을 결정하는 중요한 기능 을 한다.

$\mathrm{VMD}$ 의 연출에서 연출적 요소는 상품이 평준화되 고 유사한 종류의 경쟁 매장들이 증가하고 있는 시점 에서 상품과 서비스 그리고 매장 연출 면에서 브랜드 의 매장을 차별화 시키는 역할을 한다.

먼저 매장의 얼굴이라 할 수 있는 $\mathrm{VP}$ 는 쇼윈도와 매장 입구의 메인 스테이지, 테이블 중앙 연출 공간 으로 구분된다. 에이랜드의 매장 입구는 고객들이 매 장 안으로 쉽게 들어올 수 있도록 개방되어 있으며, 스테이지에는 많은 집기류들을 배치하여 고객들의 시선을 집중시키고, 테이블 중앙 연출 공간은 패션 액세서리와 제품이 손에 닿기 쉬운 위치에 배치 진열 하여 연출한다(Fig. 11). 원더플레이스에서는 매장의 입구와 매장 안이 바로 연결되어 있어, 고객들의 접 근이 용이하며, 매인 스테이지는 광고 이미지만으로
심플하게 연출하였으며, 테이블에는 의류, 모자, 신발 등을 함께 진열한다(Fig. 14). 어라운드더코너는 입구 에 조명과 독특한 매장 인터리어로 고객들의 시선을 끌어 매장 안으로 고객들을 유도하는 연출을 한다 (Fig. 17). 매장 내의 테이블에서는 이벤트 상품을 진 열한다. 3개 브랜드 모두 쇼윈도와 매장 입구에서 고 객들의 시선을 유도하며, 특히 매장의 문을 오픈하거 나 개방형으로 연출하여 지나가는 사람들이 쉽게 매 장으로 들어올 수 있도록 회유하는 연출에 주력하고 있었다. 특히 어라운드더코너에서는 쇼윈도와 매장 입구에 진열상품 테이블을 배치하여 지나가던 고객 들의 시선을 끌고, 브랜드 홍보와 브랜드 이미지를 자연스럽게 인식시키고 있었다. 이는 주력하고 있는 브랜드의 유행 컨셉이나 계절 컨셉을 종합적으로 나 타낸다.

판매 포인트를 나타내는 $\mathrm{PP}$ 는 페이스 상단 상품, 행거 앞 마네킹 공간을 나타내는데, 대체적으로 판매 제품 아이템의 다양성으로 연출 공간이 협소하여 페 
이스 상단에 의류단품과 가방, 모자 등의 소품을 연 관성 있게 배치하고 있었으며, 마네킹은 집기류들이 많이 있어 공간이 협소하기 때문에 전신 마네킹는 그 시즌에 가장 트렌디한 상품을 진열하고, 페이스 상단 부분을 넓게 활용하여 매장을 넓어 보이게 하여 시야 를 시원하게 확보할 수 있게 하였다(Fig. 15). 대체적 으로 페이스 상단에는 상품의 가치를 높이기 위해 모 자와 소품 등을 진열하였으며, 마네킹은 조명과 함께 연출하여 매장안의 세련미와 공간구성 연출을 하는 데 쓰인다(Fig. 18). 이처럼 고객의 구매 동선을 고려 한 연출적 요소는 고객을 매장의 구석까지 회유한다. $\mathrm{PP}$ 에서는 3 개 브랜드 모두 그 시즌에 가장 트렌디한 상품들을 진열하고 있었으며, 에이랜드의 PP가 공간 을 넓게 활용하면서 고객들에게 시원한 느낌을 가지 게 하여 가장 잘 활용되고 있었다. 하지만 각각의 다 양한 제품 연출을 효과적으로 하기에는 공간이 한정 되어 있지만, 에이랜드의 사례에서처럼 브랜드의 주 력 컨셉 연출은 브랜드만의 아이덴티티를 각인시키 므로 차별화를 위해 효과적인 활용을 고려해야 할 것 으로 나타났다.

제품의 차별화 강조를 위한 IP 연출은 행거를 활용 한 수평진열과 쇼케이스 연출 공간으로 나타났다. 고 객의 쇼핑 편의를 제공하므로 행거와 선반을 활용하 여 다양한 브랜드와 아이템을 수평 진열하여 고객들 이 보기 쉽도록 연출해야 하는 것이 중요한 것으로 나타났다(Fig. 13). 일반적으로 쇼케이스는 고가의 액 세서리와 시계, 안경 등을 진열하여 제품의 차별성을 강조하는데, 일반 매장과 비교하여 연구 대상 셀렉트 샵은 고가의 액세서리나 시계 판매가 미흡하여 저가 의 액세서리나 양말, 모자, 가방과 같은 패션 소품이 나 라이프스타일 제품을 차별적으로 진열하는데 활 용되고 있었다(Fig. 16). 〈Fig. 17〉의 어라운드더코너 에서는 관련 상품을 연계 진열하여 상품 스타일에 따 른 행거 진열을 주로 하며, 쇼케이스에서는 양말과 액세서리를 판매한다. IP에서는 3 개의 브랜드 모두 브랜드별 그룹 수평 진열을 하여 고객이 직접 제품을 고를 수 있도록 디스플레이를 연출하였으며, 가격대 형성에서 고가의 제품이 제한적인 연구대상 셀렉트 샵의 특성상 쇼케이스는 그 연출활용이 미흡한 것으 로 나타났다.

\section{Characteristics of VMD elements of fashion select shop interior display}

패션 셀렉트샵 인테리어 디스플레이는 셀프서비 스, 쇼케이스, 카운터, 환경 디스플레이 공간으로 구 분할 수 있으며, 효과적인 인테리어 디스플레이를 위 한 셀렉트샵의 VMD 구성 요소를 도출하면〈Table 2)와 같다.

먼저 셀프서비스 디스플레이는 다양한 브랜드와 디자이너의 다품종을 판매하는 매장 특성상 대표 제 품을 시각적으로 잘 보이는 입구쪽 테이블이나 선반 에 고르기 쉽도록 진열하여 고객이 직접 만져볼 수 있는 체험적 요소를 강조하는 것이다(Fig. 20). 셀프 서비스 디스플레이에서 진열적 요소를 집기, 비주얼 이미지, $\mathrm{POP}$ 로 살펴보면 다음과 같다. 집기는 주로 테이블, 선반, 행거 등을 사용하여 진열되고 있었으 며, 비주얼이미지는 광고나 포스터 외에 최근 활용도 가 높아지고 있는 디지털 파사드가 벽면이나 쇼윈도 에 배치되어 제품 정보를 고객에게 전달하며, 제품 선택을 용이하게 하고 있었다. $\mathrm{POP}$ 에서는 $\mathrm{POP}$ 와 쇼 카드, 배너를 활용하여 상품정보 및 이벤트를 고객에 게 시각적으로 전달하고 있었다. 넓은 매장에 다양한 품종의 제품이 진열되는 특성상 판매자의 도움 없이 고객이 상품을 선택하기 쉽게 품목별로 분류 및 정리 하는 디스플레이를 추구하고 있었다. 연출적 요소에 서는 고객이 직접 상품을 선택할 수 있도록 IP 요소 가 주로 활용되었는데, 편리한 쇼핑 환경 조성에 중 요하다고 할 수 있겠다.

쇼케이스 디스플레이는 패션 매장에서 유통하고 있는 고가의 시계, 액세서리, 선글라스 등의 제품의 특성과 가치를 돋보이게 하는 것이다. 쇼케이스 디스 플레이에서 활용되는 진열적 요소는 집기, $\mathrm{POP}$, 소도 구, 조명으로 나타났다. 집기는 쇼케이스가 활용되고 있었으며, $\mathrm{POP}$ 에서는 쇼카드, 정보안내지, 상품 설명 $\mathrm{POP}$ 를 통해 제품 안내 정보 제공을 하였고, 소도구를 활용하여 쇼케이스에 다양한 소품을 연출하고, 조명 을 통해 상품의 식별과 주목률을 높여 고객들에게 상 품을 돋보이게 하였다(Fig. 21). 쇼케이스 디스플레이 에서 연출적 요소는 주로 PP 연출을 중심으로 판매 포인트를 고급스럽게 강조하여 고객의 구매 욕구를 자극하였다. 그러나 젊은 소비자층을 대상으로 하는 연구 대상 셀렉트샵의 경우, 고가의 귀금속이나 시계 
등의 아이템 유통이 미흡하여 주로 쇼케이스 디스플 레이를 독창적인 디자인 제품이나 소품을 전시하는 용도로 활용하고 있었다.

카운터 디스플레이는 카운터 후면이나 측면 선반
에 패션 소품들을 진열하여 고객들의 시선을 유도하 도록 연출되었으며, 편안한 조명을 사용하여 고객들 에게 구매를 확정하는 결재시 안정감을 주도록 하고 있었다(Fig. 22). 진열적 요소로는 집기, 비주얼이미

$<$ Table 2> Characteristics of interior display

\begin{tabular}{|c|c|c|c|}
\hline \multicolumn{4}{|c|}{ Characteristics of interior display } \\
\hline \multirow[t]{2}{*}{$\begin{array}{l}\text { Self-service } \\
\text { display }\end{array}$} & (6) & $\begin{array}{l}\text { Display } \\
\text { elements }\end{array}$ & $\begin{array}{l}\text { - Elements used: Fixtures, visual image and POP are } \\
\text { mainly used. } \\
\text { - Fixtures: Table, shelf, clothes rack } \\
\text { - Visual image: Making customers feel easy to select } \\
\text { products by delivering product information to cus- } \\
\text { tomers } \\
\text { - POP: Making customers feel easy to select products } \\
\text { through product information and event notification }\end{array}$ \\
\hline & $\begin{array}{l}<\text { Fig. 20> Wonder } \\
\text { Place self-service display. } \\
\text { Photographed by the } \\
\text { author. (October } 27 \text {, } \\
\text { 2016) }\end{array}$ & $\begin{array}{l}\text { Presentation } \\
\text { elements }\end{array}$ & $\begin{array}{l}\text { - Use of IP element enabling customers to select pro- } \\
\text { ducts in person by classifying and arranging by items } \\
\text { to make customers feel easy to select products } \\
\text { - Element used: IP }\end{array}$ \\
\hline \multirow[t]{2}{*}{$\begin{array}{l}\text { Showcase } \\
\text { display }\end{array}$} & 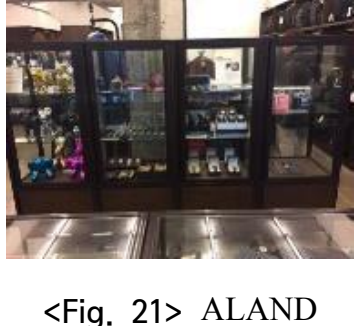 & $\begin{array}{l}\text { Display } \\
\text { elements }\end{array}$ & $\begin{array}{l}\text { - Elements used: Fixtures, POP, props, lighting } \\
\text { - Fixture: showcase } \\
\text { - POP : It provides customers with product information } \\
\text { through product explanation POP. } \\
\text { - Props : It creates various props of showcase. } \\
\text { - Lighting : It makes products stand out for customers. }\end{array}$ \\
\hline & $\begin{array}{l}\text { showcase display. } \\
\text { Photographed by the } \\
\text { author. (October 23, } \\
\text { 2016) }\end{array}$ & $\begin{array}{l}\text { Presentation } \\
\text { elements }\end{array}$ & $\begin{array}{l}\text { - Showcase display stimulates customers' purchase need } \\
\text { by emphasizing selling point in a luxurious way } \\
\text { focusing on the PP creation. }\end{array}$ \\
\hline \multirow[t]{2}{*}{$\begin{array}{l}\text { Counter } \\
\text { display }\end{array}$} & around the corner & $\begin{array}{l}\text { Display } \\
\text { elements }\end{array}$ & $\begin{array}{l}\text { - Elements used: Fixtures, visual image, POP, counter, li- } \\
\text { ghting } \\
\text { - Fixtures: Table, shelf } \\
\text { - Visual image : It enables customers to find counter } \\
\text { easily and heightens attention rate. } \\
\text { - POP : It induces customers to come to the counter. } \\
\text { - Counter : It convinces customers for purchasing. } \\
\text { - Lighting : It provides customers with a sense of stabi- } \\
\text { lity and creates a pleasure selling environment. }\end{array}$ \\
\hline & $\begin{array}{l}\text { Photographed by the } \\
\text { author. (November 03, } \\
\text { 2016) }\end{array}$ & $\begin{array}{l}\text { Presentation } \\
\text { elements }\end{array}$ & $\begin{array}{l}\text { - It creates a comfortable atmosphere by displaying pro- } \\
\text { ducts at the back side of counter, around wall stage } \\
\text { and top of shelf focusing on the PP+IP. }\end{array}$ \\
\hline
\end{tabular}




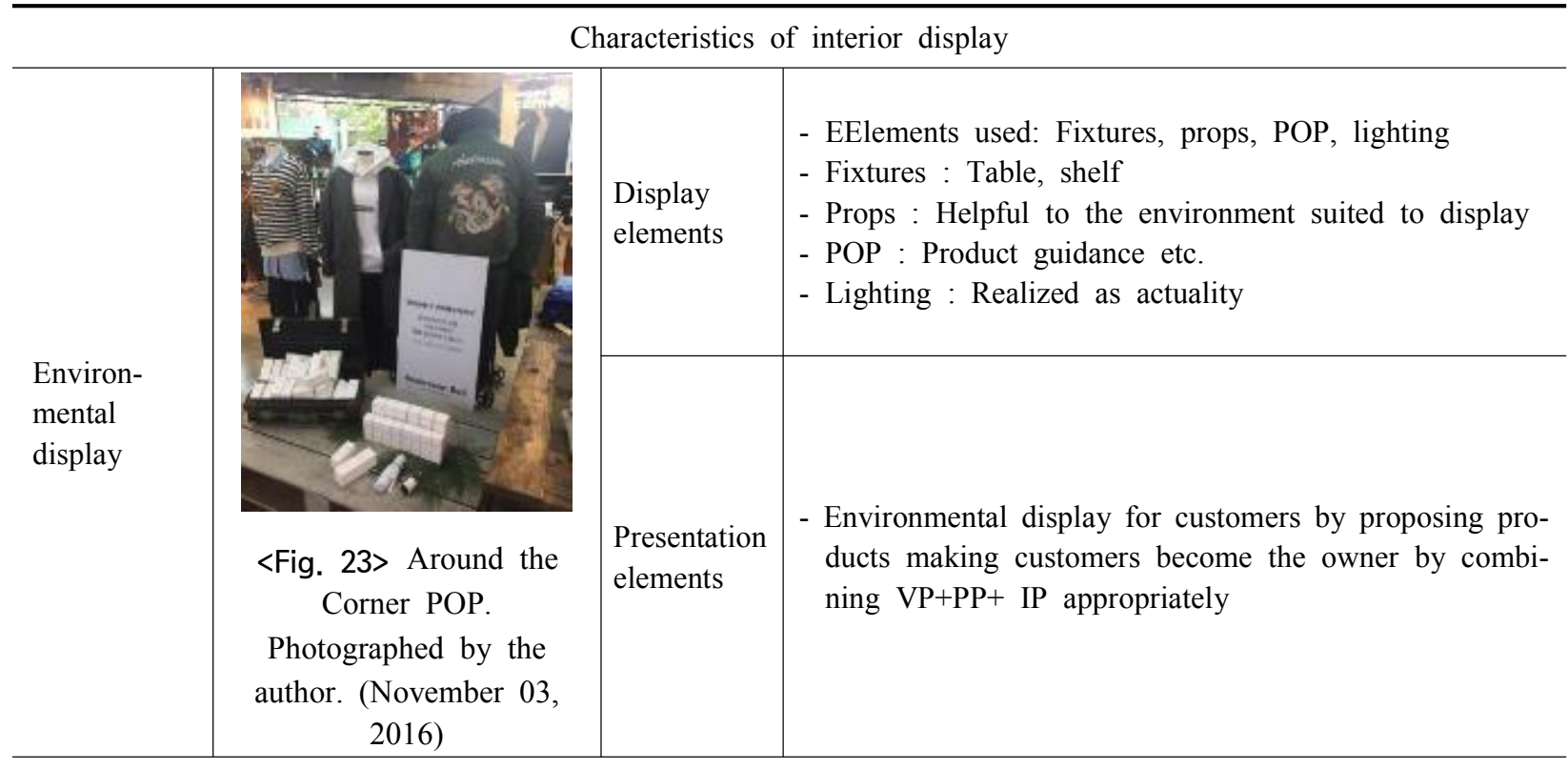

지, $\mathrm{POP}$, 카운터 등이 활용되고 있었다. 집기는 카운 터 진열에 필요한 테이블, 선반을 주로 활용하고, 비 주얼이미지에서는 카운터 뒤에 디지털 파사드를 활 용하여 카운터를 쉽게 찾도록 하면서 브랜드 제품 홍 보의 주목률을 높이고 있었다. POP에서는 신제품, 세 일, 가격정보, 프로모션 등의 $\mathrm{POP}$ 상품 제공과 정보 안내를 보고, 카운터로 회유하도록 유도하며, 편안한 조명으로 고객들에게 안정감과 즐거운 판매환경을 조성하여 고객이 구매를 하는 마지막 단계에 구매의 확신을 주도록 디스플레이 되고 있었다. 카운터 디스 플레이에서 연출적 요소에서는 PP와 IP의 연출을 중 심으로 카운터 뒷면 및 주변의 벽면 스테이지, 선반 의 상단에 제품을 포인트로 진열하고, 조명으로 편안 한 분위기를 연출하였다.

환경 디스플레이는 제품이 실제 사용되는 상황을 그대로 재현하여 고객들이 제품을 사용하지 않아도 그에 맞는 상황을 그대로 연출하게 하여 고객이 간점 체험하도록 하는 것이다(Fig. 23). 진열적 요소에서는 집기, 소도구, $\mathrm{POP}$, 조명 등이 활용되었으며, 집기에 서는 테이블이나 선반 등으로 연출되고 있었으며, 디 스플레이에 맞는 환경을 연출하도록 하며, $\mathrm{POP}$ 에서 는 POP와 쇼카드, 배너의 상품정보 및 안내를 통해 신제품을 알리고, 조명에서는 더욱더 환경 디스플레 이가 실제 상황처럼 보이도록 돕고 있었다. 연출적 요소는 VP, PP, IP를 적절히 조합하여 고객에게 시즌
트렌드를 제안하고 적용할 수 있는 정보를 제공하는 환경 디스플레이를 하고 있었다.

\section{Conclusion}

최근 소비자의 개성화 다양화에 따른 소비 추세의 변화를 반영한 셀렉트샵은 패션 중심지인 명동, 가로 수길, 홍대 그리고 대형 복합쇼핑몰에 입점하여 SPA 브랜드와 차별화된 상품과 체험 문화를 제공하고 있 다.

이에 본 연구에서는 한 매장에서 다양한 브랜드와 신진디자이너의 제품을 구매할 수 있는 패션 셀렉트 샵에서 고객의 쾌적한 쇼핑 환경과 구매 심리를 자극 시킬 수 있는 $\mathrm{VMD}$ 의 인테리어 디스플레이에 관한 연구를 통해 패션 셀렉트샵의 질적 성장을 도모하고 자 한다. VMD 구성요소는 패션 브랜드 연구에 적합 한 진열적 요소와 연출적 요소로 구분되었으며, 이를 대표 셀렉트샵인 에이랜드와 원더플레이스, 어라운드 더코너 사례를 중심으로 그 특성을 살펴보았다. 특히 매장을 방문하는 고객에게 시각적으로 다양한 제품 아이템의 정보와 홍보를 동시에 전달하여 고객을 매 장 안으로 회유하고, 구매를 촉진시키기 위한 $\mathrm{VMD}$ 전략에서 구성요소에 따른 결과는 다음과 같다.

첫째, 고객의 라이프 스타일을 반영한 다양한 컨셉 의 상품을 한 매장에서 판매하고 있는 셀렉트 샵에서 
$\mathrm{VMD}$ 는 브랜드 자체 경쟁력을 강화하고, 고객을 회 유하여 판매를 증대시키는 역할을 하는 것으로 나타 났다. 둘째, 패션 셀렉트샵 VMD 전략에서 다양한 브 랜드와 관련 품목을 유통하는 매장의 특성상 고객과 직접적으로 소통하는 효과적인 인테리어 디스플레이 기획이 필요한 것으로 고찰되었다. 셋째, 인테리어 디 스플레이는 $\mathrm{VMD}$ 구성요소에 영향을 미치는 진열적 요소와 브랜드 아이덴티티를 강조할 수 있는 연출적 요소로 살펴 볼 수 있다. 넷째, $\mathrm{VMD}$ 구성요소에서 진열적 요소와 연출적 요소는 셀렉트샵을 단지 제품 판매를 통해 수익을 올리는 마케팅 전략 외에 문화와 휴식 그리고 서비스까지 제공하는 효과적인 커뮤니 케이션 전략으로 나타났다.

패션 셀렉트샵의 인테리어 디스플레이는 한 매장 에서 의류 제품 및 액세서리와 그와 관련된 라이프 스타일 소품 등의 다양한 품목을 유통하는 매장의 특 성상 효과적으로 상품을 연출하기 위하여, $\mathrm{VMD}$ 구 성 요소 활용을 통해 매장의 효율성을 높이는 $\mathrm{VMD}$ 전략이 필요한 것으로 나타났다. 특히 고객을 매장 안으로 회유하고 다양한 상품에 흥미를 느끼게 하는 정보제공과 홍보 그리고 연출을 통해 구매를 확신하 게 하는 패션 셀렉트샵 매장의 인테리어 디스플레이 는 그 중요성이 강조되고 있다. 이에 따른 본 연구의 패션 셀렉트샵 인테리어 디스플레이를 효과적으로 연출하기 위한 $\mathrm{VMD}$ 의 구성 요소와 연출의 특성에 관한 연구 결론은 다음과 같다.

첫째, 패션 셀렉트샵 인테리어 디스플레이에서 셀 프서비스 디스플레이에서 진열적 요소는 3 개 브랜드 모두 매장 직원의 도움 없이 고객들이 제품을 쉽게 체험할 수 있도록 디스플레이 하기 위하여 테이블이 나 행거 집기를 활용하여 적극적으로 활용되고 있었 다. 연출적 요소에서는 상품 정보를 $\mathrm{VP}$ 를 통해 고객 에게 시각적으로 인식시키고, 고객이 상품을 선택하 기 쉽게 품목별로 분류 및 정리하여 고객이 직접 상 품을 선택할 수 있는 IP 요소가 중점적으로 활용되고 있었다. 이러한 매장의 효율적 운영은 고객에게 편리 한 쇼핑환경을 제공하여 구매를 창출시킨다. 이는 $\mathrm{VMD}$ 기획시 디스플레이의 목적에서 고객이 스스로 제품을 쉽게 고를 수 있는 효율성을 강조하며, 구매 를 유도하는 판매효율을 높이는 역할을 하므로 패션 셀렉트샵 인테리어 디스플레이 기획시 다양한 제품
진열과 연출시 고려해야 할 관점이라 하겠다. 패션 셀렉트샵의 특성상 한 매장에 패션상품 외에 다양한 관련 라이프스타일 제품을 함께 유통하기 때문에, 매 장에 방문한 고객이 상품을 고르기 쉽도록 매장의 인 테리어를 디스플레이하여 $\mathrm{VMD}$ 를 강화하는 것은 판 매와 관리를 용이하게 하여 효율적인 매장을 구성할 수 있다. 이러한 셀프서비스 디스플레이를 통한 상품 분류와 배치 중점의 $\mathrm{VMD}$ 기획은 구매 의욕을 높이 고, 상품 관리를 용이하게 하여 적정 재고 파악 및 상 품 회전 등을 개선시켜 비용 절감과 인력 낭비를 막 을 수 있다.

둘째, 패션 셀렉트샵 인테리어 디스플레이에서 쇼 케이스 디스플레이는 그 활용이 미흡하였다. 이는 독 창적인 신진디자이너 제품을 주력적으로 유통하고 있는 매장의 특성상 고가의 귀금속 같은 제품보다는 독창적인 패션 소품이 주를 이루기 때문이다. 원더플 레이스와 어라운드더코너는 액세서리를 테이블 위에 진열하였고, 쇼케이스를 활용하여 디스플레이하고 있 지는 않았다. 반면, 에이랜드에서는 패션 소품을 쇼케 이스를 활용하여 전시하여 상품의 가치를 부여하고, 고객들의 호기심을 유발하는 역할을 하고 있었다. 연 출적 요소에서 쇼케이스 디스플레이는 PP 연출을 중 심으로 판매 포인트를 고급스럽게 강조하여 고객의 구매 욕구를 자극하기 때문에 SPA 브랜드와 차별하 기 위한 전략으로 활용이 가능하다고 보여진다. 이러 한 쇼케이스 디스플레이를 고급화 연출을 고객의 동 선 흐름을 고려하여 배치한다면 브랜드의 상품 가치 를 높여 브랜드만의 차별적인 이미지를 형성하고 높 여 고부가가치를 창출하며, 고객의 구매동선을 매장 의 구석구석으로 회유 및 확대시킬 수 있겠다. 패션 셀렉트샵은 주로 신진디자이너의 독창적 디자인의 상품 유통을 중점으로 하고 있으므로, 대량생산되는 페스트 패션과 구별되기 위해서는 희소성이 강조되 는 창의적 디자인 제품으로 매장의 아이덴티티를 강 조할 수 있다. 인테리어 디스플레이에서 쇼케이스 디 스플레이의 적절한 활용은 매장 아이덴티티를 통해 매장내 상품 가치를 높여 매장 이미지를 높이고, 매 출 향상을 유도하여 매장의 브랜드 아이덴티티를 차 별적으로 강조할 수 있는 차별화 전략이 될 수 있다. 이와 같은 매장 아이덴티티 구축은 매장 이미지 전략 에 중요한 역할을 하므로 일관성 있는 이미지 고양이 
필요하다.

셋째, 카운터 디스플레이의 진열적 요소는 3 개 브 랜드 모두 계산대 후면이나 옆에 상품을 배치하여 디 스플레이하고 있었다. 연출적 요소에서는 PP와 IP의 연출을 중심으로 카운터 뒷면 및 주변의 벽면 스테이 지, 선반의 상단에 제품을 포인트로 진열하여 조명으 로 주목률을 높이면서 편안한 분위기를 연출하였다. 이러한 진열적, 연출적 요소의 조화로운 디스플레이 는 구매를 확신시켜 판매 촉진시킨다. $\mathrm{VMD}$ 전략에 서 인테리어 디스플레이의 $\mathrm{VMD}$ 구성 요소는 상품의 정보를 최대한 표현하여 상품이 잘 팔릴 수 있도록 유도하였다. 구매 시점에 유행하는 주력 상품과 연관 상품을 적절히 디스플레이하여 상품의 가치를 최대 한 표현하는 것은 고객에게 상품에 대한 구매 욕구를 자극시켜 매출을 촉진시킨다.

넷째, 환경 디스플레이는 고객으로 하여금 의도하 는 상품에 흥미를 느끼게 하고, 사고 싶은 구매 의도 를 가지게 하여 즐거운 쇼핑 분위기를 연출하는 특성 을 가진다. 매장 일정 공간에 연출된 제품 정보와 트 렌드를 제시하고, 상품의 이미지를 부각시켜 전체적 으로 조화로운 매장 공간을 제공하는 것이다. 제품이 실제 사용되는 상황을 그대로 재현해야 하는 특성상 일정 면적의 공간이 필요한데, 다양한 브랜드의 상품 군을 유통하는 셀렉트샵에서 환경 디스플레이의 진 열적 요소는 어라운드더코너는 환경 디스플레이를 적극적으로 활용하지 않고 있었으며, 에이랜드와 원 더플레이스는 적극적으로 매장과 제품이 조화롭게 디스플레이 되도록 하고 있었다. 연출적 요소에서는 $\mathrm{VP}, \mathrm{PP}, \mathrm{IP}$ 를 적절히 조합하여 고객이 주인이 되는 상품 제안을 하여 고객을 위한 환경 디스플레이가 중 요한데 고객이 재방문하고 싶은 매력적인 매장 연출 이 중요 관점이라 하겠다. 이러한 인테리어 디스플레 이에서 환경 디스플레이는 매장 내에서 유통하는 제 품의 상품 가치와 정보를 적정한 시기에 최대한 시각 적으로 표현하여 판매 포인트를 주어, 쾌적하고 즐거 운 쇼핑 분위기 연출을 통해 고객의 방문을 회유하 고, 구매의 기회 제공과 유도로 매출을 높일 수 있다.

이처럼 패션 셀렉트샵의 인테리어 디스플레이는 매장의 아이덴티티를 강조하는 차별된 분위기를 연 출하고, 상품이 가진 가치를 최대한 표현하여 팔리도 록 유도하는 보여주는 전략이다. 이는 패션 셀렉트
샵 매장을 방문하는 고객에게 판매 제품의 정보와 기 능을 효과적으로 전달하여 고객과 직접 소통하는 역 할을 하여 편리한 쇼핑 공간 구성과 즐거운 쇼핑 환 경을 제공하여 구매를 유도한다. 다양한 디자이너와 브랜드 그리고 아이템을 한 곳에 판매하는 셀렉트샵 의 인테리어 디스플레이 연출에서 $\mathrm{VMD}$ 구성요소는 패션 셀렉트샵 만의 브랜드 특성이 강조되도록 연출 을 돕기 때문에 매장의 특성을 고객에게 각인시켜 브 랜드 아이덴티티를 강화시키는 표현 전략이다.

대형 패션 셀렉트샵의 확대에 따라 차별적인 성장 과 고객의 구매 욕구를 충족시키기 위해서는 고객에 게 적절한 시기에 상품 정보를 제공하는 매장의 환경 을 기획해야 하고, 그에 따른 제품 판매 촉진을 위한 전략이 제안되어야 하며, 패션 셀렉트샵 만의 브랜드 이미지를 구축해야 한다. 본 연구는 인테리어 디스플 레이이의 공간 표현에 있어 $\mathrm{VMD}$ 구성 요소의 필요 성을 강조하며, 한 매장에서 다양한 패션 브랜드 상 품 외에 라이프 스타일 상품을 동시에 유통하는 최근 셀렉트샵의 트렌드를 반영한 연구로서 매장 $\mathrm{VMD}$ 활 용 방안의 기초자료가 되기를 바란다.

\section{References}

Aland. (2016, October 23). About Aland: Our story. Retrieved October 23, 2016, from http://www. a-land.co.kr/company/aland_story.php

Around the corner. (2016, November 3). Story. Retrieved November 3, 2016, from http://www.lfmall. co.kr/p2/brands/aboutCorner

Bahk, S. A. (2007). A study on the effective strategies and design methods in visual merchandising. Unpublished master's thesis, Ewha Womans University, Seoul, Korea.

Camouflage. (2012, March 3). 8ight seconds [Blog post]. Retrieved November 5, 2016, from http:// blog.naver.com/dysh21/50135715544

Camouflage. (2014, August 13). Tissot [Blog post]. Retrieved November 5, 2016, from http://blog. naver.com/dysh21/220091296949

Chae, J. S. (2012, March 29). 10 꼬르소 꼬모 서울, 4주년 맞았다 $\left[10\right.$ Corso Como Seoul, $4^{\text {th }}$ anni- 
versary]. The Asia Business Daily, Retrieved November 5, 2016, from http://www.asiae.co.kr/ news/view.htm?idxno $=2012032807414493699$

Choi, B.-B. (2009). Effects of new consumer lifestyle on evolution of fashion multi-shop. Unpublished master's thesis, Chung-ang University, Seoul, Korea.

Descente. (2016, December 14). 데상트 하남 스타필 드점을 소개합니다 [Introduces Descente Hanam Starfield store] [Blog post]. Retrieved November 5, 2016, from http://blog.naver.com/beat38/220 885870496

Eom, E.-Y. (2015). The study on select shop directed current consumption trend: Focused on change of fashion life style. Unpublished master's thesis, Hongik University Seoul, Korea.

Jang, H. N. (2010). A study on the relationship between space design elements and marketing in brand coffeeshops. Unpublished master's thesis, Cung-ang University, Seoul, Korea.

Jang, J. W. (2007). Effects of consumers' VMD recognition and composition element evaluation on the process of purchasing clothes: Comparing the departments to Dongdaemun large-scale shopping centers. Unpublished master's thesis, Hanyang University, Seoul, Korea.

Jin, X.-Y., Yoon, J.-W., \& Chong, K.-S. (2015). Research on an interior design store display skills based on VMD space representation skills: Focusing on the interior design showroom of IKEA Korea. 2015 KIID Spring Conference Proceedings, 2015(5), 38-42.

Jung, E. J. (2011). The study on VMD elements and the assessment by the user about the SPA brands store. Unpublished master's thesis, Sangmyung University, Seoul, Korea.

Jung, H.-Y. (2008). A study of department store public space VMD: Specialized in ' $L$ ' department store Centumcity branch office. Unpublished master's thesis, Dongseo University, Busan, Korea.

Jung, S. K. (2001). Marketing communications. Se- oul: Joongang M\&B.

Junjun. (2015, October 22). VP PP IP. Raim Design Institute, Retrieved November 5, 2016, from http://cafe.naver.com/raimcolorlist/14880

Kim, C. H. (2005). A study on the interior design eyewear-shop adapt to visual merchandising. Unpublished master's thesis, Sangmyung University, Seoul, Korea.

Kim, S.-E. (2003). A study on the marketing strategy for domestic fashion multi-shop dealt with imported products only. Unpublished master's thesis, Dongduk Women's University, Seoul, Korea.

Kim, K. H. (2015). The effect of the congruity between self-image and image of a multi-brand store on store attributes and consumer responses. Unpublished master's thesis, Ewha Womans University Seoul, Korea.

Kim, S. Y., \& Hwang, J. S. (2011). Classifications and strategic directions of multi-brand fashion stores in Korea. Journal of the Korean Society of Clothing and Textiles, 35(5), 587-600. doi:10. 5850/JKSCT.2011.35.5.587

Lee, Y. J. (1998). 패션 VMD: 디스플레이를 통한 브 랜드 성공 전략 [Fashion VMD]. Seoul: Mijinsa.

Oh, I.-W. (2004). The study on the Korean plastic consciousness of the contemporary interior space in Korea. Korean Institute of Interior Design Journal, 13(5), 74-81.

Park, J. A. (2015, October 13). 분더샵 청담 1주년 기 념, 'LA PROJECT' 론칭 [Boontheshop Cheongdam 1st anniversary, launched 'LA PROJECT']. Sn@pp, Retrieved November 5, 2016, from http://zine.istyle24.com/Culture/CultureView.aspx $? \mathrm{Idx}=24679 \&$ Menu $=12$

Ru, S.-Y. (2003). The effect VMD by the department store on clothing purchase behavior. Unpublished master's thesis, Sookmyung Women's University, Seoul, Korea.

Shin, H.-Y. (2003). A study on the visual merchandising manual of trendy casual dress shop. Unpublished master's thesis, Chungang Univer- 
sity, Seoul, Korea.

Sim, N. H. (2005). Visual merchandising \& display.

Seoul: Wooyong.
Wonderplace. (2016, October 27). Info. Retrieved October 27, 2016, from http://www.wonderplace. co.kr/content/content.php?cont $=$ company\&mode $=1$ 